\title{
BOTANIČAR IVO HORVAT (1897. - 1963.), RAD NA BOTANIČKOM ZAVODU VETERINARSKOG FAKULTETA SVEUČILIŠTA U ZAGREBU
}

\author{
IVO HORVAT, BOTANIST (1897 - 1963), WORK AT \\ THE DEPARTMENT OF BOTANY OF THE FACULTY \\ OF VETERINARY MEDICINE AT THE UNIVERSITY \\ OF ZAGREB
}

\author{
KsenijaVlahović*, Maja Popovićc*, Daniel Špoljarićc***
}

\begin{abstract}
SAŽETAK
Prof. dr. sc. Ivo Horvat, poznati hrvatski znanstvenik i botaničar međunarodnog ugleda, rođen je u Čazmi 7. listopada I897. Iz njegove neprocjenjive znanstvene i nastavne baštine za ovu je prigodu izdvojen tek malen dio posvećen razdoblju od II. lipnja 1947. do 23. travnja 1963. u kojem je prof. Horvat radio i boravio na Zavodu za botaniku Veterinarskog fakulteta Sveučilišta u Zagrebu. Djelovao je u širokom području prirodnih i biomedicinskih veterinarskih znanosti: od sistematske botanike, ekologije i očuvanja okoliša do proučavanja filogenije, florističkih i vegetacijskih istraživanja, uključujući vegetacijsko kartiranje te znanstveno-organizacijski rad. Slijedom bibliografskih i arhivskih izvora originalnih dokumenata, dani podaci kratki su prikaz doprinosa prof. Horvata fitocenološkom radu te pregled znanstvene i obrazovne baštine s naglaskom na godine provedene na Veterinarskom fakultetu.
\end{abstract}

Ključne riječi: Ivo Horvat, botaničar, Veterinarski fakultet, Zagreb

Veterinarski fakultet Sveučilišta u Zagrebu, Zavod za veterinarsku biologiju, Zagreb, Hrvatska. ORCID ID: 0000-0001-7521-4538.

** Veterinarski fakultet Sveučilišta u Zagrebu, Zavod za veterinarsku biologiju, Zagreb, Hrvatska. ORCID ID: 0000-0001-6210-4831.

**** Veterinarski fakultet Sveučilišta u Zagrebu, Zavod za veterinarsku biologiju, Zagreb, Hrvatska. ORCID ID: 0000-0001-7506-869X.

Adresa za dopisivanje: Ksenija Vlahović, Zavod za veterinarsku biologiju, Veterinarski fakultet Sveučilišta u Zagrebu, Heinzelova 55, 10000 Zagreb, Hrvatska. E pošta: vlahovic@vef.hr. 


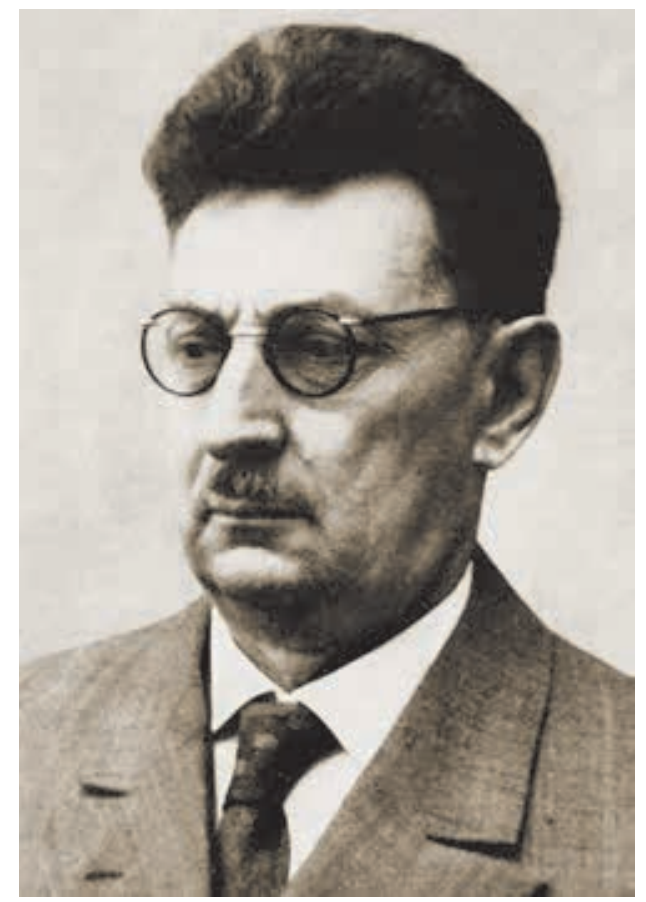

Slika I. Prof. dr. Ivo Horvat, 1897 - I963.

(Gračanin, 1963., str. 265)

Figure I. Professor Ivo Horvat, PhD, 1897-1963

(Gračanin, 1963, p. 265)

\section{UvoD}

U lipnju 2020. navršene su 73 godine od zapošljavanja profesora Ive Horvata na Veterinarskom fakultetu Sveučilišta u Zagrebu (dalje u tekstu VEF). Donjogradsku Klasičnu gimnaziju u Zagrebu završio je rgr6., a diplomirao je na Mudroslovnom fakultetu Sveučilišta u Zagrebu 1920. Doktorom znanosti iz područja botanike postao je 3I. srpnja I920. kada se zapošljava kao asistent u Botaničkom zavodu Filozofskog fakulteta. Godine 1933. postavljen je za izvanrednog profesora sistematske botanike i geobotanike na Filozofskom fakultetu u Zagrebu. Godine I940. postaje redovni profesor te predstojnik Botaničkog instituta i Botaničkog vrta Filozofskog fakulteta u Zagrebu. Na toj dužnosti ostaje do 1945. Potom odlazi u Makedoniju i tamo radi do 1947. kada se kao redoviti profesor zapošljava na Zavodu za botaniku Veterinarskog fakulteta Sveučilišta u Zagrebu. Redovni profesor i predstojnik Zavoda za botaniku VEF-a postaje II. lipnja 1947. i na tom radnom mjestu ostaje više 
od petnaest godina, sve do smrti 23 . travnja I963. ${ }^{1}$ Istaknutoga hrvatskog prirodoslovca i jednog od najznačajnijih znanstvenika botaničara svjetskoga glasa, zbog njegovih mnogobrojnih interesa, najbolje opisuje njegov znanstveni opus s više od 200 radova: 5 monografskih knjiga, 84 znanstvene rasprave u časopisima i 87 inih stručno-popularnih članaka. ${ }^{2}$ Cjelokupni pregled bibliografije prof. Horvata objavljen je u Biološkom glasniku ig $63 .^{3}$ godine. Osim znanstvenog opusa, ostavština ovoga velikog znanstvenika obuhvaća najveći osobni herbar jugoistočne Europe i niz drugih stručnih radova, recenzija, elaborata, foto dokumentacijsku zbirku od više stotina negativa te zbirku od više tisuća otisaka znanstvenih radova znakovitih svjetskih botaničara. 1 Koristeći se svojim prijašnjim dugogodišnjim istraživačkim i nastavničkim iskustvom, rad prof. Horvata dostigao je vrhunac upravo na Veterinarskom fakultetu. ${ }^{4} \mathrm{U}$ tom je smislu s povijesnoga gledišta potrebno istaknuti neke podatke ili događaje koji su obilježili njegov plodonosan nastavni i nadasve znanstveni rad u razdoblju od II. lipnja I947. do 23. travnja i963. godine. U tom je razdoblju prof. Horvat bio djelatnik Zavoda za botaniku, odnosno današnjeg Zavoda za veterinarsku biologiju. Uoči ıoo. obljetnice osnutka Veterinarskog fakulteta, djelatnici Zavoda za veterinarsku biologiju predstavili su dokumente te znanstvena i nastavna djela prof. Horvata, kojim su studentima i građanstvu nastojali približiti njegovo životno djelo i rad. Izložba je bila i dio manifestacije Noć muzeja 2019. i 2020. godine. S obzirom na krhkost i osjetljivost izvornih dokumenata, na izložbi je prikazana i digitalizirana građa u obliku postera. Ova vrijedna građa prvi je put predstavljena javnosti. Riječ je ponajprije o dokumentaciji i bogatim slikovnim materijalima iz arhive Zavoda i Fakulteta. Ovdje ćemo izdvojiti samo dio tada prikazanih materijala vezan uz doprinos prof. Horvata razvoju botanike na našem fakultetu i u Republici Hrvatskoj.

\section{ZAPOŠLJAVANJE I RAD NA VETERINARSKOM FAKULTETU SVeučilišta u Zagrebu}

U osobnom dosjeu prof. Horvata, arhiviranom na VEF-u kao službeni dokument, nalazi se rješenje o njegovu imenovanju na radno mjesto redovitog

Pleše, V. (2014), Ivo Horvat-botaničar svjetskog glasa, Hrvatske šume, 211-212, 42-3.

Rac, Mladen, Lovrić, Andrija-Željko (1997), Prof. dr. Ivo Horvat (1897 - 1963), najveći hrvatski prirodoslovac-biolog 20. stoljeća (životopis $i$ znanstveno djelo uz stotu obljetnicu rođenja), https:// www.bib.irb.hr/1361 (pristupljeno 13. veljače 2020.).

3 Bertović, S. (1963), Prof. dr. Ivo Horvat. Životopis, znanstveni rad i ostavština, Biološki glasnik, 16(3-4), A13-19.

4 Bertović, S.,Findrik, M.(1964), Prof. dr. Ivo Horvat - In memoriam, Veterinarski arhiv, 34(3-4), $53-5$. 
profesora na VEF-u, izdano na dan Ir. lipnja 1947. godine. Uz to, u posjedu smo zakletve, s njegovim potpisom, kojom je prof. Horvat izjavio da će savjesno obavljati dužnosti na Fakultetu, datiranu na 23. lipnja 1947. godine. U dosjeu se nalazi i Izjava o godinama provedenim u radnom odnosu radi utvrđivanja radnog staža, s njegovim potpisom, datirana na 4. rujna 195I.
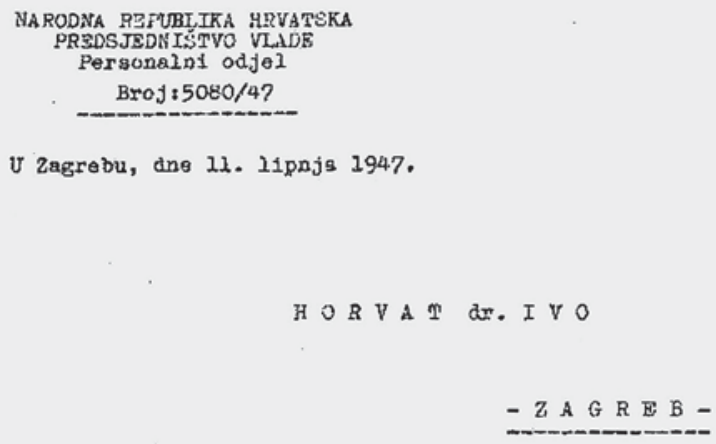

Rješenjen Predsjednika Vlade Narodie Republike Hrvatske broj gornji od danas, a na temelju čl. 47. Zakona o državnia službenicina postavljeni ste za redovnog sveučllibnog profesora kod Veterinarskog fukalteta Sveučlišta u Zagrebu sa pravom na beriva službonika II. položajne Brupo 2. stepena.

SMRT FAŠIZUU - SLOBODA NARODU !

PONOCNIK NACELNIKA Personalnos odjela:

x. 'P. J. Ivezićl

J. Ivezíc, v.r.

Slika 2. Rješenje o imenovanju na radno mjesto redovitoga sveučilišnog profesora na VEF-u od II. lipnja I947., iz arhive VEF-a

Figure 2. Decision on appointment of Prof. Horvat, PhD as full professor at the Faculty of Veterinary Medicine (II June I947), Faculty of Veterinary Medicine archives

Povijest nastave i znanstvenog rada iz botanike na VEF-u u više od I5 godina njegova rada obilježena je iznimnim intenzitetom, sadržajem i raznolikošću nastavnog i znanstvenoistraživačkog rada. ${ }^{5}$

5 Bertović, S., Findrik, M. (1964), 53-5. 
Prema navodima autora Racae i Lovrića, 1997., prof. Horvat bio je poznat kao uzoran nastavnik, vješt predavač i vatreni popularizator prirodnih znanosti. Njegova predavanja bila su uvijek dobro posjećena, čak i onda kad je predmet Botanika, čiji je bio voditelj, postao fakultativan. Predavanja i diskusije nisu bili ograničeni samo na sveučilišne predavaonice nego i na terensku nastavu u prirodi. ${ }^{6}$

Njegovi studenti i suradnici posebno su cijenili njegovu pristupačnost, odnosno uspostavu bliskog i podražavajućeg odnosa. ${ }^{7}$

U vrijeme kada je radio na Fakultetu održavao je predavanja i tečajeve i izvan matične ustanove, diljem Europe. Predavao je i ostvario prepoznatljivu međunarodnu suradnju s kolegama u Beču, Grazu, Hamburgu, Giessenu, Stolzenau, Halle/Saaleu, Varšavi, Krakovu, Zürichu i drugdje.

U domaćim razmjerima imao je izvanredno velik utjecaj kao izvrstan visokoškolski nastavnik, odnosno voditelj i savjetnik mlađih kolega botaničara u znanstvenom radu. Bio je pobornik rada u timu i uvođenja suvremenih dostignuća u struku. Time je stekao velik broj studenata i poštovatelja. ${ }^{8}$ Bio je mentor i voditelj većeg broja doktorskih disertacija i nastupnih predavanja botaničara, ekologa i biogeografa u Hrvatskoj i šire na području jugoistočne Europe. ${ }^{9}$

Došavši u Zavod za botaniku Veterinarskog fakulteta, prof. Horvat suživio se s radom institucije i počeo primjenjivati svoje golemo dotadašnje znanje $i$ iskustvo. Postao je iskreni član i s ponosom je isticao svoju pripadnost toj ustanovi. Osvajao je slušače riječima, posebno one koji su ga imali sreću slušati kao stručnjaci upoznati s problemima u samoj praksi. ${ }^{10}$

Danas djelatnici Zavoda za veterinarsku biologiju nastoje upoznati svoje studente sa životnim djelom prof. Horvata preko različitih nastavnih, znanstvenih i stručnih aktivnosti. Nakon njegove smrti predmet Botanika je ukinut, a ponovno je uveden 1998. kada se izvodi kao izborni predmet Izabrana poglavlja iz botanike do 2005. godine. Potom postaje redoviti predmet Botanika u veterinarskoj medicini, a 2or6. uvodi se i za studente koji studiraju na novo uvedenome studijskom programu Veterinarske medicine koji se izvodi na engleskom jeziku.

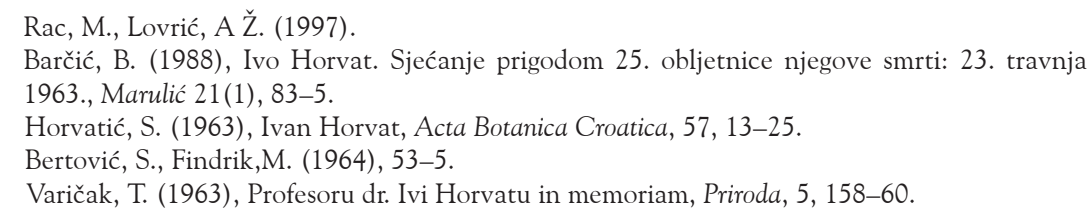


Danas svi studenti prve godine studija Veterinarske medicine sudjeluju, u okviru redovitih i izbornih predmeta, u obveznoj terenskoj nastavi u Nacionalnom parku Risnjak. U okviru propisanoga studijskog plana studentima je tako omogućeno izravno se upoznati s radom prof. Horvata. Svojim istraživanjima prof. Horvat postigao je u svakom pogledu najveće uspjehe, stvorivši temeljna djela trajne vrijednosti. Prije svega se to odnosi na njegovo iznimno zalaganje da masiv Risnjak postane nacionalni park te na istraživanja i kartiranja vegetacije šireg područja Nacionalnog parka Risnjaka. Zahvaljujući prof. Horvatu Risnjak je postao jednim od središnjih objekata geobotaničkih i vegetativnih istraživanja, kojemu je, sa svojim brojnim suradnicima iz raznih područja prirodnih, šumarskih i poljoprivrednih znanosti, posvetio mnogo godina intenzivna znanstvenog rada pa se može reći da je upravo zahvaljujući tome Risnjak postao poznat i izvan granica naše zemlje. ${ }^{11}$ Odmah po zapošljavanju na Fakultetu I948. prof. Horvat počinje detaljno kartiranje masiva Risnjaka i Snježnika. Da bi u tome uspio, okupio je istraživačku ekipu od preko pedeset stručnih suradnika. ${ }^{12}$

Ovdje posebno treba istaknuti da je, uz Risnjak, njegovim zalaganjem i suradnjom proglašeno više prirodnih rezervata i nacionalnih parkova, kao npr. Nacionalni park Pelister u Makedoniji te manji rezervati Lička Plješivica, kanjonska dolina Zelenjak kod Klanjca u Hrvatskom zagorju (prirodni i memorijalni rezervat Hrvatske himne), Cret Dubravica kod Zaprešića i dr.

U ekološko-vegetacijskom pogledu ta su područja danas botanički najbolje poznati dijelovi Hrvatske i trajne postaje za buduća složena poredbena istraživanja s različitih prirodoslovnih gledišta. ${ }^{13}$

U svrhu analize i istraživanja masiva Risnjak prof. Horvat poticao je i održavanje brojnih skupova i savjetovanja. U prilog tom navodu, iz arhive Fakulteta posjedujemo jedan od poziva na savjetovanje suradnicima koji su istraživali planinski masiv Risnjak. Iz njega je razvidno tko je sudjelovao u istraživanjima i analizi prikupljenih podataka o masivu Risnjak. Savjetovanje je održano na Fakultetu 27., 28. i 29. prosinca 1950. godine. Provedena intenzivna istraživanja bila su temelj za proglašenje Risnjaka nacionalnim parkom. Upravo je na prijedlog prof. Horvata te obrazloženja koje je napisao, Prijedlog

Horvatić, S. (1963), 13-25.

Centar za kulturu Čazma Gradski muzej Čazma 2013, Ivo Horvat-život za prirodu (uz 50 godišnjicu smrti 23. 4. 1963. - 23. 4. 2013), Čazma: Katalog izložbe.

13 Rac, M., Lovrić, A.Ž. (1997). 
za proglašenje Risnjaka narodnim parkom, prihvaćen Zakon o proglašenju šume Risnjaka nacionalnim parkom 15 . rujna I953. (Narodne novine, 43/I953). ${ }^{14}$

Osnivanje Horvatove hrvatske fitocenološke škole bilo je poticaj za daljnje sustavne vegetacijske studije, odnosno kartiranje vegetacije u našoj zemlji. Školu je završio niz istaknutih fitocenologa. ${ }^{15}$

Njegova se znanstvena djelatnost odvijala u nekoliko smjerova te obuhvaća: sistematiku i proučavanje filogenije paprati, floru mahovina, floristička i vegetacijska istraživanja, uključujući vegetacijsko kartiranje te znanstveno-organizacijski rad. Proučio je i opisao mnogobrojne šumske, livadne i ostale biljne zajednice u različitim geografskim područjima, reljefnim i klimatskim pojasovima u zemlji i širem području jugoistočne Europe. Osim što je potaknuo i proveo prva detaljna vegetacijska kartiranja masiva Risnjaka i Snježnika u Gorskom kotaru (I948.) te Pelistera u Makedoniji (I947.), na njegov prijedlog izrađene su i suvremene fitocenološke karte bivše Jugoslavije (1959. - 196r.) i Europe (1963.). Prof. Horvat je za svoje opsežne sinteze poredbeno proučavao vegetaciju u većini europskih zemalja od Francuske do Rusije i od Finske do Grčke. ${ }^{16,17}$

U razdoblju rada na Fakultetu bavio se i istraživanjima planina izvan $\mathrm{Hr}$ vatske. U prilog tome posjedujemo rješenje Fakultetskog vijeća Veterinarskog fakulteta za plaćeni dopust u okviru kojega će prof. Horvat istraživati grčke planine u trajanju od 20 dana, datirano na dan I7. lipnja ig6o., iz arhive VEF-a.

Rad prof. Horvata obilježili su dosljednost, preciznost i primjena stečenih spoznaja u različitim prirodno znanstvenim, gospodarskim i ostalim područjima, posebno u šumarstvu, poljodjelstvu, veterinarstvu i zaštiti prirode. Surađivao je s mnogobrojnim uglednim šumarima, sa šumarskom operativom, a bio je i vanjski suradnik Hrvatskoga šumarskog instituta. Ta suradnja unaprijedila je njegov istraživački i publicistički rad, ali i provedbu trajnih fitocenoloških i tipoloških istraživanja i kartiranja šuma i šumskih staništa u Hrvatskoj. Svojim radovima i raspravama iz područja fitocenologije pobuđuje veliko zanimanje kod vodećih svjetskih botaničara. Sudjeluje na brojnim inozemnim skupovima, često predaje na mnogim europskim sveučilištima, najviše u Njemačkoj i Austriji, što mu omogućava i znanje njemačkog, engle-

14 Bertović, S. (1994), Nekoliko zapaženih godišnjica Horvatovih istraživanja, kartiranja i zaštite raslinstva u Hrvatskoj, Šumarski list, 118(1-2), 43-4.

15 Domac, R. (1993), Prof. dr. Ivo Horvat - Život i djelo, Radovi Leksikografskog Zavoda Miroslav Krleža knj. 3., 215-21.

16 Pleše, V. (2014), 42-3.

17 Bertović, S., Findrik, M. (1964), 53-5. 
skog i francuskog jezika. Održavao je pojedinačna znanstvena predavanja u Zürichu, Hamburgu, Beču, Grazu i Krakowu. Sudjelovao je na međunarodnim simpozijima u Stolzenau/Weseru, Halleu/Saaleu i u Varšavi. Prisustvovao je na XIII. IPE-u (Internacionalna geobotanička ekskurzija) kroz Finsku i sjevernu Norvešku. ${ }^{18,19}$ Uspostavio je i trajno održavao veze s vodećim svjetskim i domaćim stručnjacima iz područja botanike. Sa sigurnošću se može ustvrditi da je nove spoznaje iz botanike uspješno implementirao i u veterinarsku medicinu, o čemu svjedoči više desetaka objavljenih radova.

Sasvim je razumljivo da se među njegovim objavljenim radovima nalazi i stanovit broj znanstvenih radova koji posve pripadaju području tzv. primijenjene botanike. ${ }^{20}$

U tekstu In memoriam napisanom u povodu smrti prof. Horvata, autor Glavač 1963. navodi ideje kojih se prof. Horvat držao u svom radu, a koje su danas doživjele opće priznanje. Citiramo dio navoda: „...prof. Horvat u četrdeset godina svog intenzivnog i plodnog rada posvetio je biljno-sociološkim istraživanjima naše zemlje i Balkana. Pritom se već u početku svog rada opredijelio za ideje i metode rada ciriško-monpelješke škole, koja je pod vodstvom njegovog prijatelja J. Braun-Blanqueta doživjela danas opće priznanje i osvojila sve kontinente. ${ }^{21}$

Rezultate znanstvenih istraživanja objavljivao je u brojnim časopisima i publikacijama kao što su: Glasnik Hrvatskog prirodoslounog društva (I92I. -I922.), Priroda (1922., I927., I931.,1934. - 1937., 1939., 1960.), Bulletin international de l'Académie yougoslave (1923., 1926., 1930. - 1931., 1934., 1936. - 1937.), Österreichischebotanische Zeitschrift (1923.), Hrvatski planinar (I924., I928., 1930. - I931., I935.), Acta botanica Croatica (1925., 1927., 1929., 1931. - 1932., 1934., 1962.), Geografski vestnik (1925.), Rad JAZU (1926., 1930. - 1931.), Vjesnik ljekarnika (1928., 1931.), Jahresberichtdere Naturforschenden Gesellschaft Graubündens (1929. - 1930.), Glasnik Ministarstva poljopriurede (1930.), Ljetopis JAZU (1930., 1933., 1935. - 1939., I94I.), Lički kalendar (1936.), Šumarski list (1937. - 1938., 1950. - 1951., 1955., 1958. - 1959., 1963.), Glasnik za šumske pokuse (1938.), Zaštita prirode (1938.), Geografski glasnik (1939., 1953., 1961.), Alma mater Croatica (1942.), Glasnik Biološke sekcije Hrvatskoga pirodoslovnog društva (1947., 1950., 1953., 1955.), Šumarstvo (1949.), Veterinarski arhiv ( 1950. - 1951., 1958., 1962.), Godišnjak Biološkog instituta (1952.), Naše planine (1952.), Veterinaria (1952.), Veterinarski glasnik (1954.), Vegetatio (1954.), Biološki

Pleše, V. (2014), 42-3.

Horvatić, S. (1963), 13-25.

Isto, 8.

Glavač, V. (1963), Prof. dr. Ivo Horvat - nekrolog, Šumarski list, 7-8, 340-42. 
glasnik (1956., I959. - 1960., I962.), Schweizerische Zeitschriftfür Forstwesen (I957.), Angewandte Pflanzensoziologie (1958.), Acta Societatisbotanicorum Poloniae (1959), Acta musei Macedonici scientiarum naturalium (1960.), Narodni šumar (196I.), Phyton (196r.), Berichtender Deutschenbotanischen Gesellschaft (1962.), Mitteilungender Österreichischen geographischen Gesellschaft (1962.). ${ }^{22}$

Suradnja s domaćim i inozemnim botaničarima rezultirala je i zajedničkim publiciranjem knjiga. Tako je jedanaest godina nakon smrti prof. Horvata tiskano njegovo životno djelo Vegetation Südosteuropas (Vegetacija jugoistočne Europe). Ta reprezentativna knjiga ima 768 stranica, 4I2 slika, I53 tablice i 2 vegetacijske karte. ${ }^{23}$

\section{Herbarij IVO i Marija Horvat (ZAHO)}

$\mathrm{Na}$ brojnim terenskim istraživanjima prof. Horvat skupio je bogatu i vrijednu herbarijsku zbirku. Godine i998., u povodu 35. obljetnice njegove smrti, herbarijska zbirka trajno je premještena iz Istraživačkog centra HAZU u zgradu Prirodoslovno-matematičkog fakulteta u Botaničkom vrtu (dalje u tekstu PMF), ${ }^{24}$ čiju je izgradnju davno prije inicirao sam prof. Horvat. ${ }^{25}$ Prije konačnog preseljenja zbirka se nalazila u prostorijama bivše Jugoslavenske, današnje Hrvatske akademije znanosti i umjetnosti u Zagrebu, a prije toga i na VEF-u u Zagrebu. Glavni dio herbarijske zbirke je sačuvan, poglavito zahvaljujući zauzimanju prof. S. Krvavice koji je postigao dogovor da se herbarij besplatno čuva i obrađuje u prostorijama VEF-a. Godine 1937. prof. Horvat oženio se Marijom Dvoržak (I909. - I994.) koja mu je stalno i najpredanije pomagala u svim laboratorijskim i publikacijskim radovima, kao i u obradi herbarijske zbirke. ${ }^{26}$ Marija Horvat također je bila djelatnica VEF-a is velikim je razumijevanjem uređivala njegove rukopise. Ta se pretpostavka oslanja na njezine rukopisne podatke sačuvane u pet čitko, nalivperom, ispisanih bilježnica i brižljivo otipkane etikete u herbarijskoj zbirci koje su nastale na temelju njegovih rukopisnih, terenskih etiketa.

22 Bertović, Stjepan (2002), Horvat Ivo, botaničar (Čazma, 7. X. 1897 - Zagreb, 23. IV. 1963). Hrvatski biografski leksikon, 5(Gn-H), 637-38.

23 Trinajstić, I. (1993), Prof. dr. Ivo Horvat (1897. - 1963.) hrvatski botaničar (u povodu 30. godišnjice smrti), Priroda, 83(4), 30-1.

24 Bertović, S. (2002), 637-38.

25 Regula-Bevilacqua, Lj. (1994), Ivo Horvat (VII), Priroda, 922, $20-1$.

26 Uremović, Sanja (2011), Taksonomska i korološka analiza roda Centaurea L. u Herbariju Ive i Marije Horvat (ZAHO), Diplomski rad. Sveučilište u Zagrebu Prirodoslovno- matematički fakultet. Biološki odsjek, Zagreb, 3. 
Herbarij IVO I MARIJA HORVAT (ZAHO) danas sadrži 7r.6ri listova, od kojih su pojedine skupine bilja zastupljene sa sljedećim brojevima herbarijskih listova: alge 7 , gljive 310, lišaji 28I, mahovine 4.730 te papratnjače i sjemenjače $64.829 .{ }^{27}$

Herbarijska zbirka nastala je, dakle, kao rezultat marljiva rada prof. Horvata i njegove supruge Marije Horvat i danas je neprocjenjiv dio nacionalne znanstvene i kulturne baštine Hrvatske. ZAHO je danas samostalna zbirka, a budući da nema status muzejske zbirke, nije dostupan široj javnosti već isključivo služi u znanstvene svrhe kao vrijedan izvor podataka. ${ }^{28}$

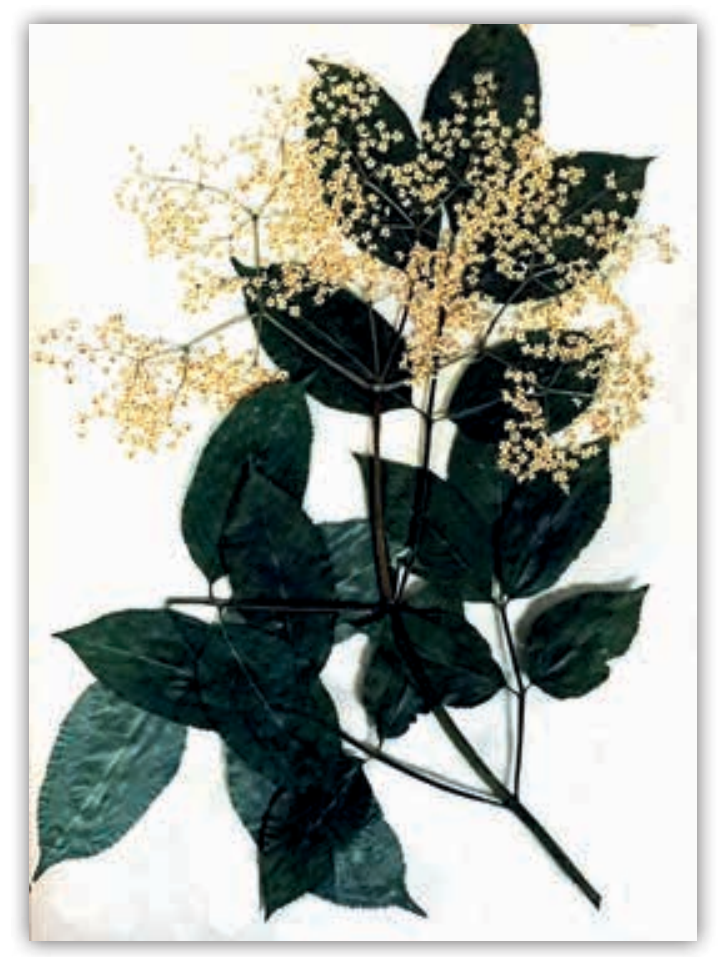

Slika 3. Edukativni materijal - originalni herbariji prof. Horvata (Izvor: Veterinarski fakultet Sveučilišta u Zagrebu)

Figure 3. Part of the educational material - the original herbarium of Prof. Horvat, PhD (Source: Faculty of Veterinary Medicine, University of Zagreb)

27 Horvat†, M., Plazibat, M. (2007), Prikaz Horvatova herbarija (ZAHO) u Zagrebu, Nat Croat, 16(4), 267-408.

28 Uremović, S. (2011), 3. 


\section{OStALE KOLEKCIJE I EDUKATIVNI MATERIJALI}

Veliku znanstvenu vrijednost imala je i njegova kolekcija fotografskih ploča, filmova i fotografija flore i vegetacije, kao i njegova znanstvena biblioteka koja sadrži niz klasičnih i suvremenih botaničkih, fitocenoloških i drugih publikacija i separata raznih autora. Ostavština prof. Horvata danas se $u$ najvećem opsegu čuva u institutu Ruđer Bošković u Zagrebu, a knjige u Nacionalnoj i sveučilišnoj biblioteci.

Prof. Horvat pokušao je zaštititi svoju znanstvenu ostavštinu sastavivši znanstvenu oporuku. Jedan primjerak te znanstvene oporuke bio je pohranjen kod njegove supruge Marije Horvat, a drugi je predao akademiku T. Varićaku s VEF-a, a po njegovoj smrti objavljena je u Biološkom glasniku. 29,30,31

$\mathrm{Na}$ Zavodu za veterinarsku biologiju čuva se i manja kolekcija edukativnih tabli i slika koju je prema (usmenoj predaji) svojom rukom izradila supruga Marija Horvat te zbirka sjemenki i plodova. Isto tako na Fakultetu je moguće još pronaći po koju fotografiju koju je tijekom botaničkih istraživanja na terenu snimio sam prof. Horvat.

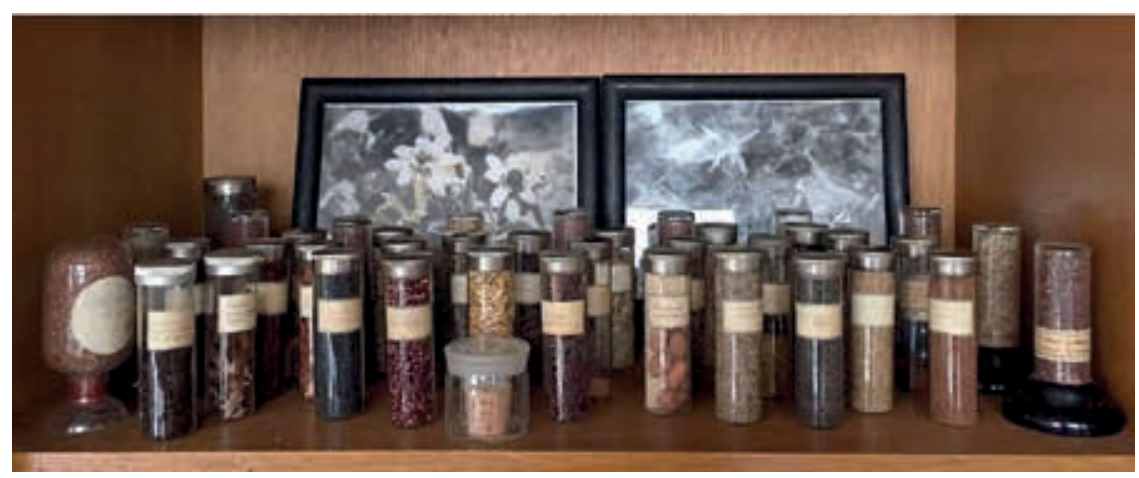

Slika 4. Dio edukativne zbirke sjemenki i plodova prof. Horvata, iz zbirke Zavoda za veterinarsku biologiju

Figure 4. Part of the educational collection of seeds and fruits of

Prof. Horvat, PhD - from the Department of Veterinary Biology archive

Na društvenom području prof. Horvat istaknuo se kao tajnik Hrvatskoga prirodoslovnog društva, član uredničkog odbora Hrvatske enciklopedije

Pleše, V. (2014), 42-3.

Rac, M., Lovrić, AŽ. (1997).

Bertović, S. (1963), A13-19. 
za područje botanike te kao član u domaćim i inozemnim povjerenstvima za zaštitu prirode. Uz to je bio član Njemačkoga botaničkog društva u Berlinu, Međunarodnog udruženja fitosociologa, izdavačkog odbora časopisa Vegetatio u Haagu, izdavačkog odbora časopisa Excerpta Botanica i Međunarodne komisije šumarskih instituta za ujednačenje metodike znanstvenih istraživanja vegetacije i silvikulture (Jufro). ${ }^{32}$

$\mathrm{Na}$ kraju treba posebno navesti još jedno djelo prof. Horvata. U perivoju VEF-a u Zagrebu ostao je, prema njegovoj zamisli, izgrađen brežuljak kao simbol Risnjaka i trajan spomen na dane boravka prof. Horvata na Fakultetu te njegov rad i angažman. ${ }^{33}$ Pritom ne treba zaboraviti da je prema njegovoj zamisli sličan brežuljak još i927. izgrađen i u Botaničkom vrtu. Prema zamisli, brežuljak je bio prikaz krške vegetacije u Hrvatskoj. ${ }^{34}$

Za svoj plodonosni pedagoški i znanstveno-istraživački rad te doprinos u promicanju hrvatske znanosti u nas i u svijetu nagrađen je priznanjima: nagradom Eugen Podaupski 1962., nagradom Ruđer Bošković 1963., a posmrtno priznanjem sa zlatnom plaketom za doprinos i unapređenje razvoja Nacionalnog parka Risnjak u povodu 3o. godišnjice postojanja. Odlukom Vlade Republike Hrvatske od 25. kolovoza 2006., Ministarstvo kulture svake godine dodjeljuje za izvanredna postignuća na području zaštite prirode godišnju nagradu i nagradu za životno djelo Ivo Horvat zaslužnim pojedincima i udrugama. ${ }^{35}$

Nakon smrti prof. Horvata, mnogi su botaničari, u počast, po njemu nazvali novootkrivene vrste biljaka, npr. V. Strgar (1965.) - Sesleria horvatii, A. Ž. Lovrić (I968.) - Centaureabracteatassp. Haynaldii (Borb.) vaur. horvatii i Allium horvatii (I97I.), F. Kušan (I969.) - Berberiscroaticassp. horvatii, Č. Šilić (1972.) Satureja horvatii, J. Markgraf (I975.) - Festuca horvatiana, B. Pawlowski Hieraciumivani, K. Micevski (I977.) - Silene horvatii i R. Lukušić (I982.) - Edraianthus horvatii. ${ }^{36}$

\section{UMJESTO ZAKLJUČKA}

Nema mnogo hrvatskih znanstvenika koji su s tolikim zanosom i općim oduševljenjem posvetili cijeli svoj život profesiji kao što je prof. Horvat posvetio botanici. Zato na kraju neka budu citirane riječi dekana VEF-a doktora

Horvatić, S. (1963), 13-25.

Bertović, S., Findrik,M. (1964), 53-5.

Regula-Bevilacqua, Lj. (1998), U spomen prof. dr. Ivi Horvatu (povodom 35. obljetnice smrti), Priroda, 852/853, 6-7.

Pleše, V. (2014), 42-3.

36 Rac, M., Lovrić, A. Ž. (1997.). 
Josipa Ivoša i njegova suradnika Stjepana Bertovića. Prisjećajući se posljednjeg susreta u bolnici s prof. Horvatom, tadašnji dekan VEF-a doktor Josip Ivoš kaže: „...Zaista je bio velik, zaista smo mnogo izgubili mi, naša zemlja. Nošen potrebom znanstvenog, stvaralačkog sagorijevanja i fizički podgrizan osobnom tragedijom, često ne govori - grize vlastito srce ili tiho govori do sebe onima sa sličnom nesrećom, smiješeći se pored bolničkog prozora zalazu sunca, rascujetanim poljima, prirodi koja traje vječno." ${ }^{37} \mathrm{Na}$ kraju prikaza života prof. Horvata, Stjepan Bertović je napisao: „...Smrt ne može utrnuti snažan plamen znanstvene misli koju je razvio Ivo Horvat ...niti izbrisati njegovo golemo zivotno djelo $i$ zastrti putove kojima danas kroči plejada njegovih suradnika i učenika u čitavoj Hrvatskoj.“38

\section{ZAHVALA}

Zahvaljujemo VEF-u, Botaničkom zavodu PMF-a i Gradskom muzeju u Čazmi, koji su nam tijekom izrade ovog prikaza o životnom djelu profesora Horvata omogućili dostupnost arhivske i muzejske građe. Posebno na pomoći zahvaljujemo prof. dr. sc. Petru Džaji s VEF-a. Zahvaljujemo i kolegi Željku Horvatu $\dagger$, dr. med. vet. i prof. dr. sc. Nori Mas, koji su se godinama brinuli i očuvali edukativne zbirke, kao i sjemenke i plodove biljaka koje su nastale kao rezultat istraživanja prof. dr. sc. Ive Horvata u razdoblju I947. - I963. godine. Riječi iskrene zahvalnosti dugujemo i prof. dr. sc. Ivi Soljačiću koji nas je podržao u nastojanju da prvi put predstavimo studentima i građanstvu razdoblje rada prof. dr. sc. I. Horvata na VEF-u.

\section{LiTERATURA}

1. Barčić, B. (1988), Ivo Horvat. Sjećanje prigodom 25. obljetnice njegove smrti: 23. travnja 1963., Marulić, 21, 83-5.

2. Bertović, S. (1963), Prof. dr. Ivo Horvat. Životopis, znanstveni rad i ostavština, Biološki glasnik, 16(3-4), A13-19.

3. Bertović, S. (1994), Nekoliko zapaženih godišnjica Horvatovih istraživanja, kartiranja i zaštite raslinstva u Hrvatskoj, Šumarski list, 118(1-2), 43-4.

4. Bertović, S. (2002), Horvat Ivo, botaničar (Čazma, 7. X. 1897 - Zagreb, 23. IV. 1963). Hrvatski biografski leksikon, 5(Gn-H), 637-38.

5. Bertović, S., Findrik, M. (1964), Prof. dr. Ivo Horvat - In memoriam, Veterinarski arhiv, 34(3-4), 53-5.

6. Centar za kulturu Čazma Gradski muzej Čazma 2013, Ivo Horvat - život za prirodu (uz 50 godišnjicu smrti 23. 4. 1963. - 23. 4. 2013.), Čazma: Katalog izložbe.

37 Polanšćak, Ž. (1963), Prof. dr. Ivo Horvat - nekrolog, Šumarski list, 7-8, 342-45.

38 Bertović, S. (1963), A13-19. 
7. Domac, R. (1993), Prof. dr. Ivo Horvat - Život i djelo, Radovi Leksikografskog Zavoda Miroslav Krleža, knj. 3, 215-21.

8. Glavač, V. (1963), Prof. dr. Ivo Horvat - nekrolog, Šumarski list, 7-8, 340-42.

9. Gračanin, Z. (1963), In memoriam Prof. dr. Ivo Horvat (1897-1963), Mitteilungen der Floristisch-soziologischen Arbeitsgemeinschaft N. F., 10, 263-282.

10. Horvat ${ }^{\dagger}$, M., Plazibat, M. (2007), Prikaz Horvatova herbarija (ZAHO) u Zagrebu, Nat Croat, 16, (4), 267-408.

11. Horvatić, S. (1963), Ivan Horvat, Acta Botanica Croatica, 57, 13-25.

12. Pleše, V. (2014), Ivo Horvat - botaničar svjetskog glasa, Hrvatske šume, 211-212, 42-3.

13. Polanšćak, Ž. (1963), Prof. dr. Ivo Horvat - nekrolog, Šumarski list, 7-8, 342-45.

14. Rac, Mladen; Lovrić, Andrija-Željko (1997), Prof. dr. Ivo Horvat (1897 - 1963), najveći hrvatski prirodoslovac-biolog 20. stoljeća (životopis $i$ znanstveno djelo uz stotu obljetnicu rođenja), https://www.bib.irb.hr/1361 (pristupljeno13. veljače 2020.).

15. Regula-Bevilacqua, Lj. (1994), Ivo Horvat (VII), Priroda, 922, 20-1.

16. Regula-Bevilacqua, Lj. (1998), U spomen prof. dr. Ivi Horvatu (povodom 35. obljetnice smrti), Priroda, 852/853, 6-7.

17. Trinajstić, I. (1993), Prof. dr. Ivo Horvat (1897. - 1963.) hrvatski botaničar (u povodu 30. godišnjice smrti), Priroda, 83(4), 30-1.

18. Uremović, Sanja (2011), Taksonomska i korološka analiza roda Centaurea L. Herbariju Ive i Marije Horvat (ZAHO), Diplomski rad. Sveučilište u Zagrebu Prirodoslovno-matematički fakultet. Biološki odsjek, Zagreb, 3.

19. Varičak, T. (1963), Profesoru dr. Ivi Horvatu in memoriam, Priroda, 5, 158-60.

\section{SUMMARY}

Professor Ivo Horvat, a world-renowned Croatian scientist, botanist, and university teacher, was born in Čazma on October 7, I897. After finishing the Classical Gymnasium in Zagreb in 19r6, he graduated from the University of Zagreb, Faculty of Philosophy in 1920 and obtained his Ph.D. in botany on July 3I, 1920. From his invaluable scientific and educational heritage, we have selected out for this occasion only a small part dedicated to the period from June II, 1947 to April 23, 1963, in which Prof. Horvat worked at the Faculty of Veterinary Medicine, University of Zagreb. He worked in a wide range of both natural and biomedical veterinary sciences: from systematic botany, ecology, and environmental protection to the study of phylogeny, floristic, and vegetation research, including vegetation mapping and scientific-organizational work. Following the bibliographic and archival sources of the original documents, the given data represent a brief overview of Prof. Horvat's contribution to phytocoenological work and an overview of scientific and educational heritage with an emphasis on the years spent at the Faculty of Veterinary Medicine, University of Zagreb.

Keywords: Ivo Horvat, Botanist, Faculty of Veterinary Medicine, Zagreb 